\title{
Histological analysis of parotid and submandibular glands in chronic alcohol abuse: a necropsy study
}

\begin{abstract}
J SCOTT,* J BURNS, $\dagger$ E A FLOWER*
From the *School of Dental Surgery and the $†$ Subdepartment of Forensic Pathology, the University of Liverpool, Liverpool
\end{abstract}

SUMMARY A quantitative histological analysis of the major salivary glands was carried out at necropsy in 28 alcoholics and in a series of age and sex matched controls. The findings were related to the different types of histologically diagnosed liver disease present. Significant quantitative changes of salivary gland structure were noted in cirrhosis but not in other forms of alcoholic liver disease. In cirrhotic subjects the parotid contained proportionally more adipose but less acinar tissues than in controls. The submandibular gland showed a proportional increase in adiposity and reduction in fibrovascular tissues but no noticeable reduction in its acinar proportional volume. Neither grossly detectable parotid enlargement nor acinar hypertrophy, a feature which has previously been noted as characteristic of alcoholic sialadenosis, were evident in this series.

These findings provide little structural support for the reportedly increased secretory capacity of salivary glands in chronic alcohol abuse.

The effects of chronic alcohol abuse eventually show themselves in most tissues and organs of the body. ${ }^{1}$ In the mouth, where alcoholism has long been aetiologically linked with oral cancer, ${ }^{2}$ we have shown that even moderate levels of drinking are associated with subclinical thinning of the surface epithelium. ${ }^{3}$ The functional importance of this atrophy or its possible relation to oral carcinoma remain unknown, but an important protective factor for the oral mucosa is the maintenance of normal salivary function. ${ }^{4}$ Moreover, several reports show that the composition and flow rate of salivary secretion is changed in chronic alcoholism, although mainly in patients with alcoholic cirrhosis. $^{.6}$

The question of whether salivary secretory changes in alcoholism derive from any change in salivary structure is difficult to determine as published reports focus principally on the condition of sialadenosis rather than on alcoholism alone. ${ }^{78}$ Sialadenosis is a clinical enlargement of the glands for which alcoholism is just one of many possible causes. ${ }^{9}$ A firm distinction has also not always been possible between the effects of alcoholism itself and those of hepatic cirrhosis. ${ }^{7-9}$

In view of the undoubted damage to oral tissues caused by chronic alcohol abuse and the importance of the protective role of saliva, we examined the major salivary glands in a series of alcoholics using quan-

Accepted for publication 2 March 1988 titative histological methods to determine the nature and extent of any changes which might have been due to alcoholism. Moreover, we examined the livers of the same subjects in an attempt to relate any salivary changes to the levels of hepatic disease induced by alcohol.

\section{Material and methods}

The alcoholics were selected at necropsy on the criteria of a known history of prolonged excessive alcohol consumption and evidence of alcoholic liver disease histologically shown in necropsy liver samples. They were divided on the basis of the hepatic changes into three groups comprising 10 subjects with alcoholic cirrhosis, 12 with alcoholic hepatitis, and six with fatty change. Similar numbers of age and sex matched controls comprised subjects, who at necropsy had no evidence or history of chronic alcoholism, and who showed complete histological absence of alcoholic liver disease. Several of these control cases, however, did have evidence of liver congestion and associated fatty degeneration of hepatocytes. The mean age for the 28 alcoholics was 52.0 years (range $30-77$ years); that for the 26 controls 52.4 years (range 28-74 years). Conditions likely to affect salivary gland histology were excluded: the presence of diabetes, lymphoma, leukaemia or rheumatoid disease, a history of drug addiction or of cytotoxic or immunosuppressive drug treatment, necropsy delayed more than $\mathbf{4 8}$ hours after 
death, and the presence of overt salivary disease or severe autolysis seen in the salivary gland sections. All cases were sudden deaths, mostly due to coronary artery insufficiency and cardiovascular accident or related conditions, or to physical trauma or suicidal overdose, which had occurred outside hospital.

The superficial lobes of one parotid gland and the whole of one submandibular gland were dissected from each case and placed in $10 \%$ neutral buffered formalin. Each gland was divided into several slices, conventionally embedded in paraffin wax, sectioned at $5 \mu \mathrm{m}$, and stained by haematoxylin and eosin. A stereological analysis was made of the salivary component tissues by stratified random sampling of the entire section area available from each gland, using a method previously described in detail. ${ }^{10}$ This entailed point counting at a rate of two points per field with the field spacing arranged to allow a minimum of 300 points to be counted per gland. The following five gland components were counted: acini, ducts, vascular tissues (both blood vessels and lymphatics), adipose tissue and other tissues, which were mainly fibrous tissue but included nerves and lymphocytic infiltrate. Lymph nodes, striated muscle, periglandular adipose tissue and major nerve trunks and vessels were excluded from the counts. The parotid count was confined to intralobular tissues on account of the difficulty of discerning accurately between septal and extraglandular fibrofatty tissues. The submandibular counts included all tissues within the gland capsule. Submandibular glands were examined in nine of the cases of alcoholic cirrhosis and their controls for which parotid glands were examined, and in one case of alcoholic cirrhosis and a matched control for which the parotid glands were not available.

The counts were made on a televised microscope image of the section at a screen magnification of $\times 1000$ using a two point grid electronically generated directly on to the monitor screen (Video position analyser, Leitz Instruments Ltd). Relative volumes of component tissues were derived from the point counting proportions. ${ }^{10}$ Mean acinar profile diameters were measured using a digitiser pad and computerised image analysis (VIDS IV, Analytical Measuring Systems Ltd, UK). At least 130 parotid acini in each case were measured from four random fields in at least three quadrants of one section. The raw data were corrected, assuming acini to be spheres of different sizes" and a corrected mean (D) calculated for each case.

Statistical testing of results from each alcoholic subgroup used the unpaired Student's $t$ test, using for comparison the combined control group of all 26 parotids, which had been formed by amalgamating the three subsets of control cases initially selected to match each of the alcoholic subgroups. Results from the 10 submandibular glands in cirrhosis were com- pared with the 10 selected age and sex matched control glands using the unpaired $t$ test. Throughout the testing the correction for inequality of variances with reduced degrees of freedom ${ }^{12}$ was used wherever necessary.

\section{Results}

\section{QUALITATIVE COMPARISONS}

There were no overt qualitative differences in parotid or submandibular salivary histology among the cases of cirrhosis, alcoholic hepatitis or alcoholic fatty liver and the control glands from non-alcoholic subjects.

PAROTID GLANDS: QUANTITATIVE DIFFERENCES The proportional volumes of parotid tissue components for each of the three alcoholic subgroups and the combined control group are given in table 1. This shows a tendency towards a higher adipose content in the alcoholic groups than in the non-alcoholic group. The difference was significant only in the cirrhotic group where the proportional volume of adipose tissue was $1 \cdot 7$-fold higher than in the combined non-alcoholic control group $(t=4.16, p<0.001)$. In the cirrhotic group the proportional volumes of both the acini and ducts were significantly lower than in the control group (acini, $t=3.63, \mathrm{p}<0.001$; ducts, $t=$ $2 \cdot 30, \mathrm{p}<0.05)$. The combined reduction in these two components, from a mean of $61.8 \%$ of gland volume in controls to $46.5 \%$ in cirrhosis, points to a loss of one fourth in the proportion of parotid glandular epithelium normally present.

The individual values for acinar and adipose proportional volumes for the cirrhotic cases and their 10 age and sex matched controls are compared in the figure. In both groups the range of values is wide, particularly for the adipose tissue.

The reduced proportional volume of vascular tissue between the cirrhotic and fatty liver groups compared with that of controls was significant for each group (p $<0.05$ (cirrhosis, $t=2.38$; fatty liver, $t=2.37$ )) (table 1). None of the other values for tissue components in either the fatty liver group or the alcoholic hepatitis group was significantly different from the values in the combined control group (table 1). In view of the discrepancy of 7.4 years in mean age between the fatty liver group and the combined control group, the means were retested using just the six designated age and sex matched control cases (mean age, 46.0 years). None of the differences, including that for the vascular components, was significant.

Comparisons were also made between the mean proportional volumes of tissue components in the three alcoholic subgroups. Significant differences ( $p<$ 0.05 ) were evident only in respect of the lower acinar proportional volume $(t=2 \cdot 12)$ and higher adipose proportional volume $(t=2 \cdot 17)$ in the cirrhotic group 
Table 1 Proportional volumes of parotid intralobular tissues from necropsies with different categories of alcoholic liver disease and from non-alcoholic controls

\begin{tabular}{|c|c|c|c|c|c|c|c|}
\hline \multirow[b]{2}{*}{ Group } & \multirow[b]{2}{*}{$(n=)$} & \multirow[b]{2}{*}{$\begin{array}{l}\text { Mean } \\
\text { age (year) }\end{array}$} & \multirow[b]{2}{*}{ Acini } & \multicolumn{4}{|c|}{ Mean (SEM) percentage of gland volume } \\
\hline & & & & Ducts & $\begin{array}{l}\text { Vascular } \\
\text { tissue }\end{array}$ & $\begin{array}{l}\text { Adipose } \\
\text { tissue }\end{array}$ & $\begin{array}{l}\text { Other* } \\
\text { tissues }\end{array}$ \\
\hline $\begin{array}{l}\text { Control } \\
\text { Cirrhosis } \\
\text { Fatty liver } \\
\text { Alcoholic hepatitis }\end{array}$ & $\begin{array}{r}26 \\
10 \\
6 \\
12\end{array}$ & $\begin{array}{l}52 \cdot 4 \\
52 \cdot 7 \\
45 \cdot 0 \\
54 \cdot 8\end{array}$ & $\begin{array}{l}53 \cdot 6(1 \cdot 95) \\
39 \cdot 7(2 \cdot 03) \\
49 \cdot 8(3 \cdot 50) \\
49 \cdot 1(3 \cdot 00)\end{array}$ & $\begin{array}{l}8.2(0.458) \\
6.7(0.287) \\
6.5(1.15) \\
7.3(0.675)\end{array}$ & $\begin{array}{l}4 \cdot 4(0.310) \\
3 \cdot 2(0 \cdot 246) \\
3 \cdot 1(0 \cdot 453) \\
4 \cdot 1(0.468)\end{array}$ & $\begin{array}{l}25.5(1.97) \\
43.4(2.37) \\
33.9(5.71) \\
31.3(3.95)\end{array}$ & $\begin{array}{l}8.4(0.776) \\
6.9(0.761) \\
6 \cdot 7(1.93) \\
8 \cdot 3(1 \cdot 19)\end{array}$ \\
\hline
\end{tabular}

*Predominantly fibrous tissue.

compared with the cases with alcoholic liver disease.

Corrected parotid mean acinar diameters were essentially no different between the cirrhotic group $\left(\bar{D}_{1}\right.$ $=44.9 \mu \mathrm{m}$, range $38.4-50.2 \mu \mathrm{m})$ and controls $\left(\overline{\mathrm{D}}_{2}=\right.$ $46 \cdot 5 \mu \mathrm{m}$, range $37 \cdot 5-51 \cdot 8 \mu \mathrm{m})$.

\section{SUBMANDIBULAR GLANDS: QUANTITATIVE DIFFERENCES}

The mean proportional volumes for tissue components of the submandibular glands in cirrhotic and age and sex matched non-alcoholic controls are given in table 2 . There was a significantly higher proportional volume of adipose tissue in the cirrhotic group $(t=$ 2.96 , df $=18, \mathrm{p}<0.01$ ). This proportional increase was offset by reductions in all the other tissues, the largest difference occurring in the fibrous component

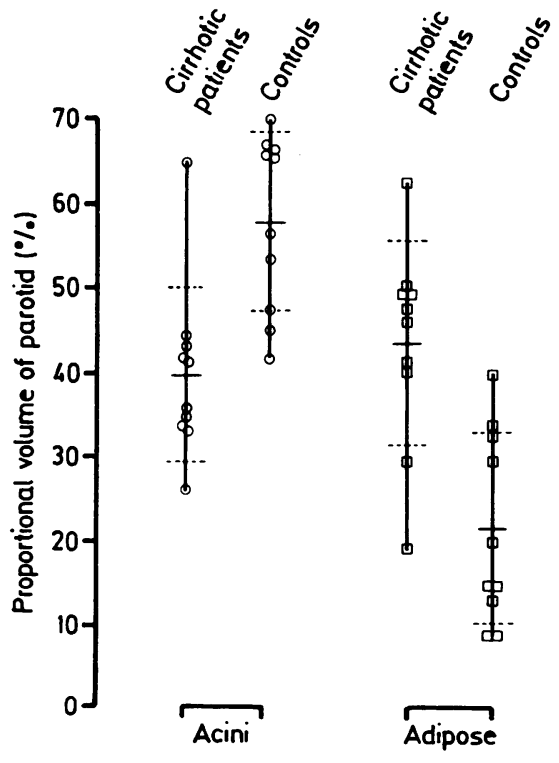

Figure Proportional volumes of acinar tissue $(O)$ and adipose tissue ( $\square$ ) in 10 cases of alcoholic cirrhosis (mean age 52.7 years) and 10 age and sex matched non-alcoholic controls (mean age 53.1 years). Horizontal bars indicate mean ( $S D)$. Reduced acinar content and increased adiposity of cirrhotics are clearly evident $(p<0.001)$.
- the "other" tissues (table 2), but this difference in means did not reach significance. For the combined fibrovascular group there was a decrease in mean proportion from $23.1 \%$ in the control group to $16.8 \%$ in the cirrhotic group, a difference which closely approached significance at $\mathrm{p}<0.05(t=2.04$, df $=$ 18).

\section{Discussion}

This report shows that salivary glands are scarcely affected in most cases of chronic alcohol abuse. Only when the disease has progressed to hepatic cirrhosis are quantitative histological salivary changes clearly detectable. At this stage the parotid gland exhibits a reduced acinar proportional volume with replacement by adipose tissue. In the submandibular gland there is little change in acinar content but additional adipose tissue is present, apparently laid down mainly at the expense of the fibrovascular component. The differences between the two glands are to a certain extent a reflection of the different counting conditions used in making the assessments (intralobular for the parotid, whole gland for the submandibular). It is important to note that the changes reported here are relative rather than absolute, and it cannot be inferred, for example, that the parotid gland is therefore depleted of its normal complement of acinar tissue in alcoholic cirrhosis.

The fatty component of the healthy parotid gland is highly variable, ranging from $7-62 \%$ of intralobular tissues. ${ }^{13}$ It follows that a high adipose content in any individual case cannot be considered as diagnostic of alcoholic cirrhosis, but the fact that both the submandibular and parotid glands showed evidence of increased adipose content in alcoholic cirrhosis is of interest. It suggests that this intraglandular adipose tissue may be the result of a generalised disturbance of fat metabolism consequent on the disturbed liver function in hepatic cirrhosis. In any case there is a tendency for the human parotid and submandibular glands to become more adipose with increasing age $\mathrm{g}^{1013}$ and the effect of alcoholic cirrhosis would seem, therefore, to accelerate this aging response. It should 
Table 2 Proportional volumes of component tissues of submandibular glands from necropsy cases of alcoholic cirrhosis and from non-alcoholic controls

Mean (SEM) percentage of gland volume

\begin{tabular}{|c|c|c|c|c|c|c|c|}
\hline \multirow[b]{2}{*}{ Group } & \multirow[b]{2}{*}{$(n=)$} & \multirow[b]{2}{*}{$\begin{array}{l}\text { Mean } \\
\text { age (year) }\end{array}$} & \multirow[b]{2}{*}{ Acini } & & & & \\
\hline & & & & Ducts & $\begin{array}{l}\text { Vascular } \\
\text { tissue }\end{array}$ & $\begin{array}{l}\text { Adipose } \\
\text { tissue }\end{array}$ & $\begin{array}{l}\text { Other* } \\
\text { tissues }\end{array}$ \\
\hline $\begin{array}{l}\text { Alcoholic cirrhosis } \\
\text { Controls }\end{array}$ & $\begin{array}{l}10 \\
10\end{array}$ & $\begin{array}{l}51.9 \\
52.6\end{array}$ & $\begin{array}{l}51 \cdot 4(2 \cdot 54) \\
55.9(1 \cdot 30)\end{array}$ & $\begin{array}{l}10.3(1.07) \\
11.6(0.90)\end{array}$ & $\begin{array}{l}4.2(0.34) \\
5.0(0.58)\end{array}$ & $\begin{array}{r}21.4(3.40) \\
9.5(2.15)\end{array}$ & $\begin{array}{l}12 \cdot 7(1.90) \\
18 \cdot 1(2 \cdot 09)\end{array}$ \\
\hline
\end{tabular}

*Predominantly fibrous tissue.

be noted, however, that in contrast to increasing adiposity, fatty degeneration of salivary parenchymal elements was not a detectable feature of the parotid or submandibular glands from either the cirrhotic or other alcoholic groups.

One of the most commonly quoted changes affecting the parotid gland in alcoholic cirrhosis is a clinically painless enlargement which may be severe enough to constitute sialadenosis..$^{6-9}$ Only two of the parotid glands from 28 alcoholic subjects reported here were apparently enlarged at necropsy. This discrepancy between our findings and those in published reports possibly reflects a greater sensitivity towards mild degrees of parotid enlargement on the part of clinical staffs in departments of oral medicine and surgery ${ }^{6-9}$ as well as differences in the facial contours in life and death. What is clear from our results, however, is that gross parotid enlargement or sialadenosis is not a common feature of chronic alcoholism, at least in the Merseyside population. This conclusion is borne out by our own clinical observations, ${ }^{14}$ as well as by those of experienced clinicians of the Mersey Regional Alcohol and Drug Dependence Unit, who encounter obvious parotid enlargement only rarely among their patients. (JS Madden, personal communication).

The careful examination of acinar size in the present study provided no evidence for even small degrees of acinar hypertrophy, although this has been described as a characteristic finding in alcoholic cirrhosis. ${ }^{79}$ Again, where this feature has been reported in alcoholic subjects it has mostly been in relation to sialadenosis. Our failure to show acinar enlargement, therefore, may reflect the absence of gross glandular enlargement in the cases of our series. It was of interest, however, that the acinar transection diameters in each of the individual cases measured showed close approximation to a normal distribution, suggesting that the assumption of a range of acinar size rather than a uniformly sized acinar population in each case is essentially correct. ${ }^{11}$

Apart from increased salivary gland adiposity in alcoholic cirrhosis, there is no general salivary structural abnormality associated with chronic alcohol abuse. Specifically, there is no structural change to correlate with the higher salivary flow rates sometimes found in alcoholism. ${ }^{5614}$ We suggest, therefore, that any salivary hyperfunction in alcoholism is more likely to be a result of physiological changes such as changed blood flow and distribution within glands consequent on the haemodynamic changes of alcoholism ${ }^{5}$ rather than a function of acinar hypertrophy, ${ }^{6}$ but should haemodynamic changes indeed occur in salivary glands in alcoholism, the evidence from our study is that they are not accompanied by any detectable increase in vascular tissue in the glands. In fact, in every comparison of vascularity made throughout this study between alcoholic and non-alcoholic subjects, the proportions of vascular tissue in the alcoholic groups were always lower than in controls.

\section{References}

1 Sherlock S. Alcohol and disease. Br Med Bull 1982;38:1-2.

2 Wynder EL, Bross IJ. Aetiological factors in mouth cancer. An approach to its prevention. Br Med J 1957; i:1137-43.

3 Valentine JA, Scott J, West CR, St Hill CA. A histological analysis of the early effects of alcohol and tobacco usage on human lingual epithelium. J Oral Pathol 1985;14:654-65.

4 Tabak LA, Levine MJ, Mandel ID, Ellison SA. Role of salivary mucins in the protection of the oral cavity. J Oral Pathol 1982;11:1-17.

5 Durr HK, Bode JCh, Gieseking R, Haase H, vArnim I, Beckmann B. Anderungen der exocrinen Function der Glandula parotis und des Pankreas bei Patienten mit Leberzirrhose und chronischem Alkoholismus. Verh Dtsch Ges Inn Med 1975;81:1322-4.

6 Abelson DC, Mandel ID, Karmiol M. Salivary studies in alcoholic cirrhosis. Oral Surg 1976;41:188-92.

7 Borsanyi S, Blanchard CL. Asymptomatic enlargement of the parotid glands. JAMA 1960;174:20-3.

8 Mandel L, Baurmash H. Parotid enlargement due to alcoholism. $J$ Am Dent Ass 1971;82:369-73.

9 Seifert G, Mietilke A, Haubrich J, Chilla R. Diseases of the salivary glands. Stuttgart: Georg Thieme-Verlag, 1986:78-84.

10 Scott J. Quantitative age changes in the histological structure of human submandibular salivary glands. Arch Oral Biol 1977;22:221-7.

11 Aherne WA, Dunnill MS. Morphometry. London: Edward Arnold, 1982;76-9.

12 Bailey NTJ. Statistical methods in biology. London: English Universities Press, 1974:47-51.

13 Scott J, Flower EA, Burns J. A quantitative study of histological changes in the human parotid gland occurring with adult age. $J$ Oral Pathol 1987;16:505-10.

14 Vicary K, Baxter P, Scott J. Parotid function in chronic alcoholism without overt liver disease. J Dent Res 1988;67:

15 Gliner JA, Horvath SM, Browe AC. Circulatory changes due to alcohol, anxiety and their interactions. Proc Soc Exp Biol Med 1978;158:604-8.

Requests for reprints to: Dr J Scott, School of Dental Surgery. The University of Liverpool, Pembroke Place, PO Box 147, Liverpool L69 3BX, England. 